\title{
OBESITY IMPACT ON RESPIRATORY FUNCTION
}

\author{
Anca Hâncu' ${ }^{1}$ Florin Mihălțan² \\ ${ }^{1}$ Nutriscience Clinic, Bucharest \\ ${ }^{2}$ Carol Davila" University of Medicine and Pharmacy, Bucharest, Romania \\ Corresponding author: Anca Hâncu \\ E-mail: ancahancu@gmail.com
}

\begin{abstract}
Not so much emphasize in literature and studies, obesity consequences on respiratory function may influence chronic obstructive pulmonary disease COPD and asthma, triggering important healthcare issues. Pulmonary function is a mortality predictor. The largest populational study European Community Respiratory Health Survey shows the impact of overweight and obesity on pulmonary function by decreasing forced expiratory volume in first second FEV1 and forced vital capacity FVC.

By the contrary, weight loss is decreasing both. Inflammatory and mechanical mechanisms should be considered in lung function impairment, as a consequence of obesity. Important aspect, lifestyle, will consider tobacco, physical activity, diet. Adopting a healthy lifestyle with a Mediterranean Diet MD will preserve a good pulmonary function on long term. We detailed below specific dietary recommendations, favorable nutrients or foods to be avoided.

In conclusion comprehensive lifestyle interventions should become populational based interventions for a better prevention for pulmonary diseases and NCD's and finally for a better health status.
\end{abstract}

Keywords: obesity, asthma, COPD, nutritional intervention, nutritional status, respiratory function.

\section{Rezumat}

Deși nu sunt atât de mult subliniate în literatura medicală și studii, consecințele obezității asupra funcției respiratorii pot influența boala pulmonară obstructivă cronică (BPOC) și astmul, declanșând probleme medicale importante. Funcția pulmonară este un predictor al mortalității. Cel mai amplu studiu populațional, European Health Respiratory Health Survey, arată impactul supraponderalității și obezității asupra funcției pulmonare, prin scăderea volumului expirator forțat în prima secundă (FEV1) și a capacității vitale forțate (FVC).

Dimpotrivă, pierderea în greutate îmbunătățește ambii parametri. Mecanismele inflamatorii și mecanice ar trebui luate în considerare în afectarea funcției pulmonare, ca o consecință a obezității. 


\section{INTERNAL}

\section{General Reviews}

Schimbarea stilului de viață este un aspect important, luând în considerare fumatul, activitatea fizică, dieta. Adoptarea unui stil de viață sănătos, cu o dietă mediteraneană, va contribui la păstrarea unei funcții pulmonare bune pe termen lung. Vom prezenta, în continuare, recomandări dietetice specifice, nutrienți favorabili sau alimente care trebuie evitate.

În concluzie, intervențiile cuprinzătoare asupra stilului de viață ar trebui să devină intervenții populaționale pentru o prevenire mai bună a bolilor pulmonare și, în cele din urmă, pentru o stare mai bună de sănătate.

Cuvinte cheie: obezitate, astm, BPOC, intervenție nutrițională, stare nutrițională, funcție respiratorie.

\section{Healthcare impact of pulmonary diseases and obesity}

Almost 64 mil DALY lost by $\operatorname{COPD}^{(1)}$ and a mortality of 3,2 mil/year, which increased in latest years by $11,6 \%$ (2015 vs 1990); 0,4 mil people who died from asthma, but mortality decreased by $26,7 \%$ in the same period are important healthcare issues. And worldwide, prevalence is still increasing for both, by $44,2 \%$ for COPD and $12,6 \%$ for asthma. Globally the Global Burden of Disease GBD study conducted by Soriano et al is showing these impressive numbers: $63850^{\text {th }}$ DALY lost from COPD and $26169^{\text {th }}$ DALY lost from asthma.

This is the context, and lung function may be considered a predictor of morbidity and mortality from noncommunicable diseases, even not so much emphasized in literature until now. In order to better quantify the size of this populational issue, more updated measurements, at populational level should be performed and benchmark with other noncommunicable diseases and their association with other exposures, like air pollution, environmental exposure, smoking, ageing. First step in chronic respiratory diseases prevention should be the maintenance of a good lung function. Main risk factors in developing pulmonary diseases are genetics, poor growth in utero and or childhood, anatomical, physiological immunological changes in times, smoking, viral and bacterial infections, environmental pollution, nutritional status, meaning both, obesity and undernutrition, diet, sedentarism. 
Lifestyle changes are important measures that should be applied, both in prevention and pulmonary diseases management, as part of multidisciplinary interventions. Increased numbers of life-years in good health will be the result of populational prevention measures combined with multidisciplinary disease management.

Another public health issue is obesity. Worldwide, almost 2 billion adults were overweight and 671 million obese in $2016^{(2)}$ As a risk factor for many chronic diseases, like cardiovascular diseases, diabetes, liver diseases and respiratory diseases, obesity has not been so much correlated with pulmonary diseases, despite the fact that many previous studies proved this correlation. Early detection of impaired lung function, as indicator of respiratory injury is leading to a better diagnosis of airways dysfunction.

Not surprisingly, abdominal obesity is associated in many studies with lung function impairment. Is important to mention the newest classification of abdominal obesity from $2020^{(3)}$ a result of the consensus statement of two prestigious societies working group on visceral obesity.

It proposes waist measurements as important opportunity for practitioners for a better obesity management. Waist circumference WC is a positive predictor of mortality, but BMI is not related to this death risk. The better ability of WC in predicting health outcomes compared to $\mathrm{BMI}$ might be related to identify increased VAT mass, which is actually the source of multiple pathogenetic mechanisms.

The group is recommending as an important target for treatment the WC decrease for reducing health risk for male and females. Treatment options comprise nutritional interventions endorsed by routine, moderate physical exercises.
Previous gaps have been identified, actual classification is more sensitive, adjusting WC based on BMI and sex. Proper training is important in order to introduce this new classification as a routine practice.

In the future, waist circumference measurements should become a standard for general practitioner, as the Consensus group accepted it as " vital sign ".

In this review we would like to address the detrimental effect of overweight and obesity, mainly abdominal obesity to lung function and possible lifestyle interventions.

\section{Material and methods}

We have searched database and we found 3522 articles related to obesity and lung function. From these we selected newest, with appearance later than 2018. Meanwhile, articles with data about lifestyle, and physical activity correlated with lung function, asthma and COPD have been evaluated in order to obtain a whole picture about pulmonary diseases and lifestyle, mainly their correlation with obesity.

\section{Significant studies conclusions: ECRHS ${ }^{(4)}$}

Many cohort and populational studies are proofs of the detrimental effects of obesity, leading to lung function decline. The most detailed data have been obtained during the longest multicentric population based study, The European Community Respiratory Health Survey ECRHS.

This is the most comprehensive populational study, multicentric, following for 20 years a large population of 18000 adults, during 3 phases: ECRHS I (1991-1993), ECRHS II (1999-2003), ECRHS III (2010-2014) with very detailed information on BMI, lifestyle factors and spirometry measurements. 


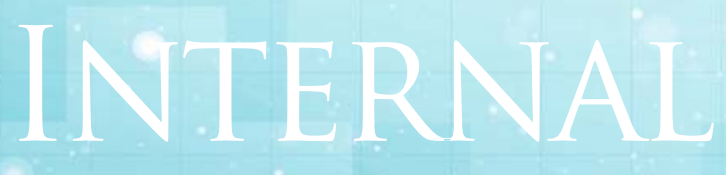

General Reviews

Spirometry evaluated forced vital capacity (FVC) and forced expiratory volume in first second (FEV1), as markers of lung function. For weight changes evaluations has been considered: weight loss $-0.25 \mathrm{~kg} /$ year, stable weight $+/-0.25 \mathrm{~kg} /$ year, moderate weight gain $0.25-1 \mathrm{~kg} /$ year. Asthma diagnosis was noted. Lifestyle elements have been recorded: smoking status, leisure time, physical activity. Generalized estimation equation was used to estimate lung function trajectories, appreciating FEV1, FVC, FEV1/ FVC evolution. Main results of this study are summarized in Table 2.

What conclusions can be drawn? Weight gain, for all people, overweight, normal or obese at baseline, is leading to an accelerated decline of FVC and FEV1, meaning practically an accelerated decline of pulmonary function. Sex stratification during analysis evidenced a marked decline of FVC and FEV1 in male gaining weight compared to females, mainly in obese category but without FEV1 / FVC ratio changes. The mechanical effects mechanism will explain below these differences in the context of more frequent male abdominal obesity compared to females. The proportional decrease of FEV1 and FVC for overweight and obese could be interpreted in the context of the possible development of a restrictive syndrome ${ }^{(5)}$, typical for obese adults. This conclusion is also in line also with all research about "obesity paradox "revealing that in COPD people with overweight have a lower mortality vs underweight patients, benefit recorded only below the level of BMI of $32 \mathrm{~kg} / \mathrm{m}^{2}$, but not above this value ${ }^{(6)}$. Rapid lung function decline in COPD is associated with: emphysema severity, smoking and frequency of acute exacerbations. COPD management has to identify these factors ${ }^{(7)}$ but, still, what precisely influence lung function decline is not known ${ }^{(8)}$.

Observational studies mentioned low BMI as a mortality predictor in COPD ${ }^{(9-12)}$. Obesity paradox, in contrast is showing the protective effect on mortality when BMI is high.

It could be surprisingly, but for underweight group, FVC and FEV1 decline is attenuated, being a positive effect, but the decline of the ratio FEV1/FVC is accelerated, meaning that an airflow limitation, typical for obstructive pulmonary syndrome may be favorized.

Very important is that for obese people at baseline, weight loss is bringing benefits, showing practically the importance of comprehensive lifestyle interventions, mainly nutritional interventions in obese patients for maintaining a good pulmonary function. The complex analysis from ECRHS allowed to see weight change effects on lung function on different weight categories followed on long term throughout adult life. We will analyze below what possible mechanisms could be involved. 


\begin{tabular}{|l|l|l|l|l|}
\hline $\begin{array}{l}\text { Body mass index } \\
\text { Waist } \\
\text { circumference }\end{array}$ & $\begin{array}{l}\text { Normal } \\
\text { weight } \\
(\mathbf{1 8 . 5 - 2 4 . 9 )}\end{array}$ & $\begin{array}{l}\text { Overweight } \\
\mathbf{( 2 5 - 2 9 . 9 )}\end{array}$ & $\begin{array}{l}\text { Obese I } \\
\mathbf{( 3 0 - 3 4 . 9 )}\end{array}$ & $\begin{array}{l}\text { Obese II and } \\
\text { III (=35) }\end{array}$ \\
\hline Women & $=80$ & $=90$ & $=105$ & $=115$ \\
\hline Men & $=90$ & $=100$ & $=110$ & $=125$ \\
\hline
\end{tabular}

Table 1. New 2020 abdominal obesity classification

\begin{tabular}{|l|l|l|l|}
\hline $\begin{array}{l}\text { Baseline- young } \\
\text { adulthood }\end{array}$ & $\begin{array}{l}\text { During follow up } \\
\text { for 20years }\end{array}$ & $\begin{array}{l}\text { At the end of the } \\
\text { study FVC, FEV1 }\end{array}$ & $\begin{array}{l}\text { FEV1/FVC at the } \\
\text { end of the study }\end{array}$ \\
\hline $\begin{array}{l}\text { Normal BMI, } \\
\text { overweight and }\end{array}$ & Weight gain & $\begin{array}{l}\text { Accelerated decline } \\
\text { of FVC and FEV1 }\end{array}$ & $\begin{array}{l}\text { No evidence of } \\
\text { decline }\end{array}$ \\
\hline $\begin{array}{l}\text { Obesity } \\
\text { Underweight in } \\
\text { young adulthood }\end{array}$ & Weight loss & $\begin{array}{l}\text { Attenuated FVC and } \\
\text { FEV1 decline }\end{array}$ & $\begin{array}{l}\text { No evidence of } \\
\text { decline }\end{array}$ \\
\hline & Atable weight & And FEV1 decline & $\begin{array}{l}\text { FEV1/FVC ratio } \\
\text { decline }\end{array}$ \\
\hline
\end{tabular}

Table 2. Lung function trajectories, appreciating FEV1, FVC, FEV1/ FVC evolution

\begin{tabular}{|l|l|l|l|}
\hline Mediated \% of CRP & Correlated WC & WHR & WHtR \\
\hline As with FEV1 & 7.96 & 9.59 & 5.76 \\
\hline As with FVC & 8.33 & 11.4 & - \\
\hline
\end{tabular}

Table 3. Mediated proportions of CRP 


\section{INTERNAL}

\section{General Reviews}

\section{Mechanisms involved in lung function decline}

\section{a) Mechanical effects on lungs ${ }^{(4)}$}

Visceral fat mass and thoracic fat reduce FVC by limiting lung expansion which turns to expiratory flow limitation. Observed different results by sex may be explained according to more frequent male abdominal obesity with a direct mechanic impact on lung function. But, in ECRHS there are not compliance measurements or systemic inflammation markers related to obesity. In conclusion, results evidenced in this study could not been distinguished, to be attributable to mechanical or inflammatory effects. In abdominal obesity important fat depots are accumulated in abdominal cavities and mediastinum, limiting mechanical properties of the lung, with the result of a reduced compliance in the lungs ${ }^{(13,14,15)}$. This is likely to lead to respiratory symptoms typical in obesity: orthopnea(16), dyspnea(17) and wheezing $^{(18)}$. In obesity there is an increase in pleural and intra-abdominal pressure, diaphragm movements are reduced and chest wall is restricted due to fat accumulation inside abdominal and thoracic cavities $^{(19,20)}$. Functional residual capacity FRC and expiratory reserve volume ERV will be reduced consecutively in obesity. Several studies have reported that in obesity both, lung compliance and chest wall are reduced $^{(13,14,15,21)}$. The decrease in lung volumes that is induced by obesity may be a major contributor to the lower lung compliance, even tissue mechanics will not be affected ${ }^{(22)}$.

\section{b) Inflammatory processes}

Adipose tissue is not an inert organ, but rather a systemic modulator of the response to environmental exposures and a potential target for novel therapeutic interventions. Meanwhile, adipose tissue is a source of inflammatory mediators that can damage tissue and reduce airway diameter ${ }^{(2)}$ Meanwhile, is an organ that secretes adipokines, adipocyte- derived factors that could affect airway function. Their expression is different for obese subjects compared to lean subjects. This aspect was the subject of research mainly for obese asthmatic patients . A pro-inflammatory adipokine, leptin is increased in asthma, mainly at obese patients ${ }^{(23)}$. Beyond the anorexigenic role, leading to an accelerated metabolism and modulatory immune function, leptin has a role also in the ventilatory drive regulation ${ }^{(24,25)}$. Leptin is involved in neonatal lung development and surfactant production $^{(26,27)}$. Considering these, the pathogenic involvement of leptin in airway disease becomes more and more relevant. A strong association of high serum leptin levels and high BMI is seen in adults asthma 
patients. For both type of patients, with and without asthma, many investigators reported peak expiratory flow PEF and spirometric indices improvement after weight loss. Is important to understand that the obesity induced pathological effect is not permanent and weight loss may restore respiratory physiology.

Very well described in a cross sectional study on 3442 Chinese participants ${ }^{(2)}$ the possible mechanism of systemic inflammation explaining the pathogenesis relating obesity with lung function decline is an important perspective. Each unit increase in waist circumference WC has been associated with FEV1 and FVC decrease, 3,39 $\mathrm{ml}$ respective $3,96 \mathrm{ml}(\mathrm{p}<0.05)$. Waist- hip-ratio WHR and Waist to Height Ratio WHtR increase by $1 \%$ was correlated with decrease in FEV1 by 5,70 $\mathrm{ml}$ and FVC by $16,92 \mathrm{ml}(\mathrm{p}<0.05)$. The correlation between lung function and abdominal obesity was mediated by plasmatic $C$ reactive protein $C R P$, suggested the study.

Plasma CRP is playing a mediating role in the association between abdominal obesity and lung function, shows the mediation analysis, using MEDIATION described by Valeri ${ }^{(29)}$. Mediated proportions of CRP are shown in the Table 3. Higher plasma CRP levels is more frequent at older smokers with higher BMI, WHtR, WC,WHR but lower FVC and FEV1, being less active and eating mainly home prepared meals. The Chinese study ${ }^{(2)}$ shows that each increase by $1 \%$ in WHtR and WHR has been associated with 0.010 and 0.012 elevated level of plasma CRP, statistical significant $(p<0.05)$. Significant FVC and FEV1 decline is shown in category analysis as long as CRP is increasing. Interestingly, plasma CRP was not found to be associated with FEV1/ FVC ratio. Chinese results found negative association between abdominal indices representing abdominal obesity and FVC and FEV1, but negative association between plasma CRP and FEV1 and FVC. In this study, BMI could not be correlated with lung function, other studies being inconclusive, too ${ }^{(29,30,31)}$. Another British study performed on 2633 people didn't find an association between FEVI, FVC and $\mathrm{BMI}^{(32)}$, consistent with Chinese study. But for a group of smokers, BMI was inversely associated with lung function ${ }^{(33)}$. The distribution of body fat is important in the correlation with lung function, abdominal obesity being mainly correlated with FVC and FEV1 decrease, for that reason WC, WHR could be more accurate measurements in predicting lung function compared to BMI. In conclusion, the correlation between WC, WHtR, WHR mediated by plasma CRP is supporting the fact that systemic inflammation may be the mechanism beyond the association between abdominal obesity and decreased lung function.

\section{c) Metabolic dysregulation}

Lung function is affected by metabolic imbalance observed in metabolic syndrome. Airways smooth muscle ASM proliferation and epithelial damage could be induced by dyslipidemia and insulin resistance ${ }^{(34,35)}$. Restrictive pulmonary syndrome is linked to metabolic syndrome, obesity but not diabetes in elderly patients ${ }^{(36,37)}$. Higher level of insulin resistance are seen in patients with a restrictive pattern compared to those with obstructive lung disease or healthy subjects.

\section{Lifestyle impact on pulmonary function - smoking}

Smoking is the leading recognised risk factor for chronic respiratory diseases. This link between lung function and smoking is 


\section{INTERNAI}

General Reviews

already well studied. Looking to the lifestyle interaction with obesity and smoking the algorithm became more complex. It seems that smoking risk is substantially greater than obesity in low income countries ${ }^{(38)}$.

Rate of death for smokers is three fold higher at middle age vs non smokers if we are looking to other common risk factors as alcohol use, obesity patterns, social status ${ }^{(38)}$. Smoking is accelerating the loss of lung function. This is very evident in COPD where different mechanical pathways are altered . In a sample of COPD patients it had been shown the presence of shorter telomeres compared with healthy smokers, and correlations between telomere shortening, premature senescence and lung inflammation was already reported in some studies ${ }^{(39)}$. Smoking affects differently: is associated with an accelerated loss in lung function in individuals with short telomeres and with little/no effect in those with longer telomeres. This short telomere length in peripheral leucocytes might be a marker for increased susceptibility to the effect of smoking ${ }^{(40)}$.

The variability in telomere length is influenced not only by genetic factors but by modifiable lifestyle factors such as smoking, obesity, physical activity or diet. Phenotyping remains important if we have to judge smokers lung function. The small airways COPD phenotype, present in younger people, with less emphysema, a preserved lung diffusion and a slower rate of lung decline is more frequent in smokers vs non-smokers ${ }^{(41)}$. Another evidence of this relation - obesity, smoking-lung function is coming from asthmatic patients. We already know that smoking is inducing a progressive airways hyper responsiveness (AHR) with a peak at elderly asthmatic people. Higher AHR was found in elderly obese; but obesity was considered a higher AHR risk factor only in subjects aged $>65$ years $^{(42)}$.

For asthmatic obese waist to height ratio and insulin resistance can predict impaired lung function and also this insulin resistance can modify the association between excessive adiposity and respiratory function ${ }^{(43)}$.

Reduced lung function can be a predictor of future development of T2D independently of obesity, smoking and inflammation, as has been shown by The Korean Genome and Epidemiological Study which included 7583 non diabetics, aged 40-69y, followed for 12 years. The association correlates incident T2D with lung function predicted forced vital capacity \%PFVC and predicted forced expiratory volume in first second \%PFEV1, but not with FEV1/FVC ${ }^{(44)}$.

Prenatal and childhood exposures is with important impact on lung development, lung function trajectory, and incidence and prevalence of respiratory disease. Avoiding known detrimental exposures including maternal smoking during pregnancy and 
initiation of active smoking, sustaining policies promoting reduction of populationlevel risk factors (restriction even on electronic cigarette sales and legislation to uphold air quality standard) bring some benefits like a maximal lung function and a reduce risk of chronic lung disease ${ }^{(45)}$.

Studies of exposure to vaping, both in humans and animals have been associated with several pathophysiological alterations in the lung functions (evaluated by the forced expiratory volume in one second (FEV1) and the ratio of forced expiratory volume to forced vital capacity (FEV/FVC),combined with reported effects on the airway mucociliary clearance and dysregulated repair mechanisms. Many compromising factors are implicated like flavors, tetrahydrocannabinol (THC oil), vitamine $\mathrm{E}$ Acetate etc are involved in this new disease generated by e cigarette disease EVALI ${ }^{(46,47)}$. The best method to avoid death caused by smoking is early quitting, before the age of $40^{(48)}$.

\section{Physical activity and lung function improvement $^{(49)}$}

- There is a growing evidence that physical activity has a beneficial effect in maintaining pulmonary health ${ }^{(50)}$.

- Hunt Study ${ }^{(50)}$ - Physical activity and lung function decline in adults with asthma was still unclear, recently was evaluated in Hunt study. A mean follow-up of 11.6 years in 1329 people has been done in a population cohort from Norway. As a result of this study is noticed that for active participants the mean FEV1 decline was $32 \mathrm{ml} /$ year, lower compared to $37 \mathrm{ml} /$ year characteristic for inactive participants. Difference is $-5 \mathrm{ml} /$ year, $95 \% \mathrm{Cl}$. Meanwhile, FVC decline was $31 \mathrm{ml} /$ year for physical active adults and $33 \mathrm{ml} / \mathrm{year}$ for sedentary participants. FEVI/FVC decline was statistically significant lower, $0,22 \%$ vs $0,36 \%$ for inactive asthmatic persons. Mean decline observed in peak expiratory flow PEF was slower for active asthmatics - $10 \mathrm{ml} /$ year compared to 14 $\mathrm{ml}$ / year observed for inactive people. In conclusion, physical activity is correlated with a lower decline in lung function for people with asthma. That means in asthma physical activity should be promoted as part of management tool, message supported by Global Initiative for asthma, too ${ }^{(51)}$.

Similar recommendations have been suggested in COPD $^{(52)}$. Hayley et al, in their review, have shown that 21 (60\%) clinical practice guidelines included in this review provided specific recommendations for physical activity. Most recommended activities are: walking, cycling, strength training and other non-specific aerobic exercises. The context for performing physical activity is to include it in person's lifestyle and social life, in recreational clubs, independently or at home. Four from six guidelines included in the review recommended for COPD patients to be active as long as their capacity allows it or until breathless ${ }^{(53,54,55)}$.

Duration should be from $20 \mathrm{~min}$ to 45 min/day. In severe COPD short intervals rather than continuous activity is indicated ${ }^{(56)}$. Frequency should be regularly, under supervision ${ }^{(57,53,58)}$. The most suggested strategy to improve physical activity is active encouragement from health care providers (57\%) and education $(11,31 \%)$ but also an exercise training program (17\%).

Physical activity, lung function and proinflammatory lifestyle risk factors: 


\section{INTERNAI}

\section{General Reviews}

- Current smokers, characterized by a systemic inflammatory burden will benefit more from anti-inflammatory effects of physical activity ${ }^{(59,60,61,62)}$.

- Another pro-inflammatory risk factor for lung function decline is the exposure to air pollution. Individuals exposure to air pollution during outdoor physical activity may affect pulmonary function? The interplay between physical activity, lung function and air pollution is important to be understood.

In order to answer this question many studies have been developed. The largest is ECRHS, which collected extensive lifestyle information from 18000 adults, using questionnaires.

Individuals were classified as physically active when the frequency of exercises was 2 times/ week at least $1 \mathrm{~h}$ and otherwise were considered non-active. In ECRHS, the combination of duration and frequency characterizing physical activity has been positively associated with FVC, FEV1, but also with decreased bronchial hyperresponsiveness ${ }^{(59)}$.

Pollution in ECRHS II was estimated by the model LUR-was $31 \mathrm{ml} /$ land use regression ${ }^{(59)}$. It was designated the individual level of air pollution for home addresses. Then, as confirmatory analysis, it was created a set of markers of NO2, PM2.5 mass and PM10 mass exposure. Observed results, mean FEV1 was lower among those living in high pollution areas (NO2 and PM10 mass).

For smokers, physical activity was improving FVC and FEV1 independent of air pollution level. But physical activity for non-smokers was correlated statistically significant with higher average FVC and FEV1 for those living in areas where air pollution was low.

\section{Effect of weight loss on pulmonary function}

ECRHS shows the attenuated lung function decline for subjects with obesity or overweight that lost weight in time (63-70). Is important to understand mechanisms that could explain this association:

1. Mechanical load on lungs will decrease during weight loss, improving lung function, this could be the first mechanism;

2. Second, systemic inflammation will be reduced in the meantime with weight loss, and that can attenuate lung function decline which is related to excessive weight. Previous research revealed that air pollution affects lung function via systemic inflammation and air quality improvement will attenuate lung function decline $^{(71)}$.

3. Another proposed mechanism is related to the decrease of metabolic alterations 
observed after weight loss, after removal of excessive adipose tissue, glycemic levels, insulin resistance, hyperlipidemia will be improved $^{(72,73)}$.

4. Other confounding factors should be taken into consideration, lifestyle improvement is more complex and changing diet, staring physical activity or quitting smoking could all bring beneficial effects on lung function ${ }^{(74,75,76,77)}$.

More research on lifestyle factors involved in lung function evolution will bring additional data on this subject.

The role of nutritional intervention in lung function improvement/ prevention

Adherence to Mediterranean Diet, as a predictor of lung function was evaluated in a study using data from Health and Retirement Study HRS. There have been evaluated 2108 adults, aged 50 and more, Med Diet score was calculated and peak expiratory flow PEF was measured. Results observed in this cross sectional study: a medium Med Diet score of 28, meaning a moderate adherence to MD correlated with lung function $(95 \% \mathrm{Cl}, 0,039$ $0,104)$. A positive association has been established between PEF rate $(p<0.05)$ and an important food category: dairy, grains and fish. High adherence to Mediterranean Diet is associated with lower incidence of PEF rate $<80 \%$ from predicted value (OR: $0.65,95 \%$ $\mathrm{Cl}: 0.48-0.89)$.

Based on these results it can be assumed that a high MD score is a good predictor of lung function in adults. Nutritional interventions may be possible preventive interventions and should be indicated especially for persons at high risk of pulmonary disease. Mediterranean Diet represent an evidence based intervention with protective role in lung function maintenance ${ }^{(78,79)}$.

\section{Healthy lifestyle in pulmonary diseases}

When a pulmonary disease is already developed, a multidisciplinary team, with pneumologist, nutritionist and even kinetotherapist should take care to recommend a healthy lifestyle with optimal diet, physical activity, good sleep and mindfulness based cognitive therapy. Rehabilitation programs does not include yet nutrition in their activity, but it could be a future plan.

\section{Medical nutrition therapy MNT for patients with obesity and COPD}

As a priority in obesity, for patients with COPD, muscular mass should be considered, due to the fact that muscular mass decrease is an important mortality risk factor. Recommended protein intake is $1,2-1,5$ $\mathrm{g} / \mathrm{kg} / \mathrm{day}^{(80)}$. There is a need for specific guidelines in this area.

Macronutrients will represent: proteins 15$20 \%$, fats $30-45 \%$, carbohidrates $40-55 \%$ from total energy intake. Macronutrients proportion is important in order to achieve the optimal respiratory quotient $R Q$, marker for respiratory tolerability for the recommended dietary pattern. RQ is the report between $\mathrm{CO} 2$ expired and the volume of $\mathrm{O} 2$ consumed. The value is 1 when the diet is based only on carbohydrates, 0.85 for a mixed diet, 0.82 for a protein diet, 0.7 for fats and 0.65 in ketosis. Vitamin C is necessary, $75 \mathrm{mg} /$ day for females and $90 \mathrm{mg} /$ day for males; for smokers an additional amount of $35 \mathrm{mg} /$ day should be added. Recommended daily intake for vitamin D should be $600 \mathrm{IU} /$ day, at >70y, $800 \mathrm{IU} /$ day, daily sun exposure. Calcium and Magnesium plasmatic values should be tracked ${ }^{(81)}$. Energy requirements for COPD obese patients should be adapted to their activities and will be measured by bioimpedance and calorimetry. 


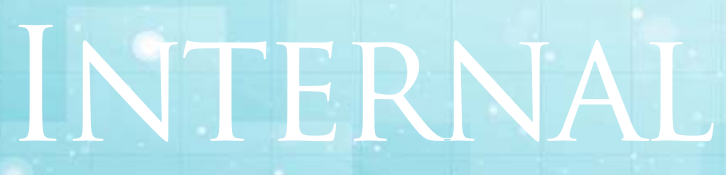

General Reviews

Obesity paradox, was already mentioned, the dilemma in COPD with obesity is to recommend weight loss and achieve a better cardiovascular prognosis but could lower lung performance? ${ }^{(82,83)}$.

And which nutritional intervention will be the best in order to have an optimal weight? Actual data associate $\mathrm{BMI} \sim 30 \mathrm{~kg} / \mathrm{m}^{2}$ with highest survival rate $^{(6)}$, but this benefit disappear at BMI $>32 \mathrm{~kg} / \mathrm{m}^{2}$. Then, the possible lifestyle intervention will be: caloric restriction, in order to maintain a BMI level $\sim 30 \mathrm{~kg} / \mathrm{m}^{2}$ (meaning we will not encourage weight loss for overweight people), high protein intake and physical exercises to strengthen muscular mass.

Pulmonary rehabilitation is the multidisciplinary intervention that improves effort capacity, dyspnea, healthcare access, including physical activity trainings. This intervention should include nutritional intervention and maybe in the future mindfulness based cognitive therapy in order to obtain complex results and a better quality of life.

\section{MNT and lifestyle recommendations for patients with obesity and asthma}

In asthma, 2019 Guideline for obesity management for general practitioners, elaborated by European Association for the Study of Obesity (84) is suggesting a $7-8 \%$ weight reduction for obese asthma patients in order to obtain an improvement of $\mathrm{FEV}_{1}$.

New guidelines for asthma lifestyle recommendations have been published in Breathe, 2019(85). As dietary pattern, Mediterranean diet MD, high in vegetables, fruits, omega 3 and fibers is related to antiinflammatory pathways. Cross sectional studies are showing asthma control improvement by adherence to MD.

\section{Specific nutrients analysis:}

- Sodium. Increased sodium intake is very common in western diets and the link with asthma could be established due to changes in sodium transport across smooth muscle cells, which could affect properties of airway smooth muscle ${ }^{(86)}$. Not clearly documented by clinical research for asthma ${ }^{(87)}$ current general recommendations that include avoiding added salt and highly processed food should be followed.

- Antioxidants. A negative role in plasma development is played by oxidative stress ${ }^{(88)}$. Nutritional interventions in asthma should address an antioxidant diet, with beneficial effects on lung airways inflammation, asthma control and lung function ${ }^{(89)}$. Fruits and vegetable intake was proved to reduce asthma exacerbations risk ${ }^{(90)}$. Vitamin $\mathrm{C}$, despite its well known antioxidant effect is lacking 
in evidence and more research is needed to establish it as a tool in asthma management. Dietary fiber are important in order to maintain a healthy microbiome; Short Chain Fatty Acids SCFA's, produced by commensal bacteria after a proper intake of fibers exert an anti-inflammatory effect. Probiotics are effective in the reduction of systemic inflammation ${ }^{(91)}$. Probiotics, present in yoghurt, kefir are living microorganisms that may increase gut bacteria benefits. Microbiome modulation can be relevant in asthma ${ }^{(92)}$. Synbiotics, with a potential immune function improvement should ameliorate asthma outcomes. A RCT showed that 4 weeks of symbiotics intake decreased cytokine production without any effect on bronchial inflammation ${ }^{(93)}$. More research is needed in this area, but still a healthy microbiome is a good asset.

- Omega 3 fatty acids, found in salmon, sardines and herring ${ }^{(85)}$ exert antiinflammatory properties by pathways involving airway hyperresponsiveness. Despite the fact that supplementation with n3 poly-unsaturated fatty acids PUFA was proposed as a support in asthma treatment, evidence is contradictory. Guidelines are suggesting that people with asthma should follow general recommendations for fish intake. An important meta-analysis showed a decreased risk of hospitalized asthma exacerbations after vit D supplementation. Sunlight exposure 10-15 min / day on arms and face, 2-3 times per week is recommended to avoid vit $\mathrm{D}$ deficiency. Some practical advices for people with asthma: vit D supplementation will exert protective effects against acute respiratory infections and will reduce exacerbation rate. As main sources: salmon, sardines, orange juices, fortified milk, eggs. Due to tocopherol vit E may decrease the risk of some asthma symptoms like wheezing or cough. Good sources are broccoli, hazelnuts, almonds. Sulfits should be avoided, causing worsening asthma symptoms. They are found in many dried fruits, leading to adverse reactions.

- A light bronchodilator, caffeine can be found in coffee and tea may support asthma treatment ${ }^{(85)}$. A systematic review found that 5-10 $\mathrm{mg}$ caffeine/kg body weight ameliorates lung function after 4 hours of consumption ${ }^{(85)}$. Maximum allowed caffeine intake per day is $400 \mathrm{mg}$. The bronchodilator effect will appear after 4-5 cups of coffee. But this recommendation is valid only if other comorbidities are not limiting this quantity.

Physical activity should support a healthy nutritional intervention in asthma. In asthma 3-5 days per week ${ }^{(94)}$ with 20-60 min should be recommended, to reduce wheezing and exacerbations, except exercise induced bronchoconstriction EIB. However, EIB should be prevented by anticipated treatment with short acting beta-agonists SABA's and exercise should be regularly. Little evidence is exploring different styles of physical activity. In conclusion, in asthma, a lifestyle intervention with antioxidant diet, with caloric adjustment to obtain a healthy weight, plenty of fruits, vegetables, and dairies, characteristic for MD will be appropriate and regular physical activity, quitting smoking, mindfulness approach and a healthy sleep should be included.

Mindfulness based cognitive therapy could be a support in asthma treatment and should be considered as a part of pulmonary rehabilitation 


\section{Conclusions}

Obesity impact on lung decline is well explained by mechanical and inflammatory mechanisms. Significant studies, like the large ECRHS have shown on long term an accelerated decline in FVC and FEVI consecutively to weight gain and an attenuated lung function decline after weight loss. Smoking, Western diet, sedentarism as unhealthy lifestyle factors may affect lung function and are risk factors for pulmonary function decline. Nutritional intervention with a healthy MD is the key element of a healthy lifestyle, accompanied by physical activity, non smoking status good sleep and mindfulness. Comprehensive lifestyle interventions should become populational based interventions for a better prevention for pulmonary diseases and NCD's and finally for a better health status.

\section{Conflict of interest statement}

Authors declare there are no conflicts of interests related to this subject.

\section{References:}

1. Joan B. Soriano \& al ,Global, regional, and national deaths, prevalence, disability-adjusted life years, and years lived with disability for chronic obstructive pulmonary disease and asthma, 19902015: a systematic analysis for the Global Burden of Disease Study 2015, GBD 2015 Chronic Respiratory Disease Collaborators, Lancet Respir Med 2017; 5: 691706

2. Heng He, Bin Wang, Min Zhou, Limin Cao, Weihong
Qiu, Ge Mu, Ailian Chen,Shijie Yang,Weihong Chen,Systemic Inflammation Mediates the Associations Between Abdominal Obesity Indices and Lung Function Decline in a Chinese General Population Diabetes, Metabolic Syndrome and Obesity: Targets and Therapy 2020:13141150141

3. Robert Ross, Ian J. Neeland, Shizuya Yamashita, Iris Shai, Jaap Seidell,Paolo Magni, Raul D. Santos, Benoit Arsenault, Ada Cuevas, Frank B. Hu ,Bruce A. Griffin, Alberto Zambon, Philip Barter, Jean- Charles Fruchart ,Robert H. Eckel, Yuji Matsuzawa and Jean-Pierre Després, Waist circumference as a vital sign in clinical practice: a Consensus Statement from the IAS and ICCR Working Group on Visceral Obesity, Nature reviews Endocrinology, published online, $04^{\text {th }}$ of February 2020

4. Gabriela P. Peralta GP, et al. Body mass index and weight change are associated with adult lung function trajectories: the prospective ECRHS studyThorax 2020

5. Zammit C, Liddicoat H, Moonsie l, et al. Obesity and respiratory diseases. Am J Clin Hypn 2011; 53:33543.

6. Anca Hâncu ; Nutritional status as a risk factor in COPD-state of the art ; Maedica- a Journal of Clinical Medicine, 2019; 14(2): 140-143.

7. Vogelmeier CF, Criner GJ, Martinez FJ, Anzueto A, Barnes PJ, Bourbeau J, et al. Global strategy for the diagnosis, management, and prevention of chronic obstructive lung disease 2017 report: GOLD executive summary. EurRespirJ. 2017;49(3):1700214

8. Ref Paradox: Yilan Sun, Stephen Milne, Jen Erh Jaw, Chen Xi Yang, Feng Xu, Xuan Li, Ma'en Obeidat and Don $D$. Sin, BMI is associated with FEVI decline in chronic obstructive pulmonary disease: a meta-analysis of clinical trial, Respiratory Research (2019) 20:236

9. Landbo C, Prescott E, Lange P, Vestbo J, Almdal TP. Prognostic value of nutritional status in chronic obstructive pulmonary disease. Am J Respir CritCare Med. 1999;160(6):185661.

10. Schols AMWJ, Slangen J, Volovics L, Wouters EFM. Weight loss is a reversible factor in the prognosis of chronic obstructive pulmonary disease. Am J Respir Crit Care Med. 1998;157(6):17917. 
11. Hasegawa W, Yamauchi $Y$, Yasunaga $H$, Sunohara $M$, Jo $T$, Matsui $H$, et al. Factors affecting mortality following emergency admission for chronic obstructive pulmonary disease. BMC Pulm Med. 2014;14:151.

12. Gudmundsson G, Ulrik CS, Gislason T, Lindberg E, Brondum $E$, Bakke $P$, et al. Long-term survival in patients hospitalized for chronic obstructive pulmonary disease: a prospective observational study in the Nordic countries. Int J Chron Obstruct Pulmon Dis. 2012;7:5716. 13. Pelosi P, Croci M, Ravagnan I, et al. The effects of body mass on lung volumes, respiratory mechanics, and gas exchange during general anesthesia. Anesth Analg 1998 9;87(3):65460

14. Hedenstierna G, Santesson J. Breathing mechanics, dead space and gas exchange in the extremely obese, breathing spontaneously and during anaesthesia with intermittent positive pressure ventilation. Acta Anaesthesiol Scand 1976;20(3):24854

15. Sharp JT, Henry JP, Sweany SK, et al. The total work of breathing in normal and obese men. J Clin Invest 1964 4;43:72839

16. Ferretti $A$, Giampiccolo $P$, Cavalli $A$, et al. Expiratory flow limitation and orthopnea in massively obese subjects. Chest 2001 5;119(5):14018

17. Sin $D D$, Jones $R L$, Man SF. Obesity is a risk factor for dyspnea but not for airflow obstruction. Arch Intern Med 2002 7;162(13):147781

18. Schachter LM, Salome CM, PeatJK, et al. Obesity is a risk for asthma and wheeze but not airway hyperresponsiveness. Thorax 2001 1;56(1):48. (PubMed: 11120896)

19. Sugerman $H$, Windsor $A$, Bessos $M$, et al. Intraabdominal pressure, sagittal abdominal diameter and obesity comorbidity. J Intern Med 1997 1;241(1):719

20. Behazin N, Jones SB, Cohen RI, et al. Respiratory restriction and elevated pleural and esophageal pressures in morbid obesity. J Appl Physiol (1985) 2010 1;108(1):2128

21. Pelosi $P$, Croci $M$, Ravagnan I, et al. Total respiratory system, lung, and chest wall mechanics in sedatedparalyzed postoperative morbidly obese patients. Chest $19961 ; 109(1): 14451$.

22. Ubong Peters and Anne E. Dixon, The effect of obesity on lung function, Expert Rev Respir Med. 2018 September; 12(9): 755767

23. Sideleva $O$, Suratt $B T$, Black $K E$, et al. Obesity and asthma: an inflammatory disease of adipose tissue not the airway. American journal of respiratory and critical care medicine 2012 101;186(7):598605

24. Polotsky VY, Smaldone MC, Scharf MT, et al. Impact of interrupted leptin pathways on ventilatory control. J Appl Physiol (1985) 2004 3;96(3):9918.

25. Bassi M, Furuya WI, Menani JV, et al. Leptin into the ventrolateral medulla facilitates chemorespiratory response in leptin-deficient (ob/ob) mice. Acta Physiol (Oxf) 2014 5;211(1):2408.

26. Torday JS, Powell FL, Farmer CG, et al. Leptin integrates vertebrate evolution: from oxygen to the blood-gas barrier. Respir Physiol Neurobiol 20108 31;173 Suppl:S3742.

27. De Blasio MJ, Boije M, Kempster SL, et al. Leptin Matures Aspects of Lung Structure and Function in the Ovine Fetus. Endocrinology 2016 1;157(1):395404.

28. VLaVT J. Mediation analysis allowing for exposuremediator interactions SAS and SPSS macros. Psychol Methods. 2013;18(2):137150. doi:10.1037/a0031034

29. Frohlich $M$, Imhof $A$, Berg $G$, et al. Association between $C$-reactive protein and features of the metabolic syndrome a population-based study. Diabetes Care. 2000;23(12):18351839.

30. Vatrella A, Calabrese C, Mattiello A, et al. Abdominal adiposity is an early marker of pulmonary function impairment: findings from a mediterranean Italian female cohort. Nutr Metab Cardiovasc Dis. 2016;26(7):643648. doi:10.1016/j.numecd.2015.12.013 31. Sin DD, Jones RL, Man SFP. Obesity is a risk factor for dyspnea but not for airflow obstruction. Arch Intern Med. 2002;162(13):1477.

32. Fogarty AW, Lewis SA, McKeever TM, Britton J. The association of two different measures of body habitus with lung function: a population-based study. Respir Med. 2011;105(12):18961901.

33. Pistelli F, Bottai M, Carrozzi L, et al. Changes in obesity status and lung function decline in a general population sample. Respir Med. 2008;102(5):674680.

34. Agrawal A, Mabalirajan U, Ahmad T, et al. Emerging interface between metabolic syndrome and asthma. Am J Respir Cell Mol Biol 2011 3;44(3):2705. doi: 10.1165/rcmb.2010-0141TR.

35. Dekkers BG, Schaafsma D, Tran $T$, et al. Insulininduced laminin expression promotes a hypercontractile airway smooth muscle phenotype. Am J Respir Cell Mol Biol 2009 10;41(4):494504.

36. Scarlata S, Fimognari $F L$, Cesari $M$, et al. Lung function changes in older people with metabolic syndrome and diabetes. Geriatr Gerontol Int 2013 10;13(4):894900. doi: 10.1111/ggi.12026.

37. Fimognari FL, Pasqualetti $P$, Moro $L$, et al. The association between metabolic syndrome and restrictive ventilatory dysfunction in older persons. J Gerontol A Biol Sci Med Sci 2007 7;62(7): 760

38. Jha $P$. ,The hazards of smoking and the benefits of cessation: a critical summation of the epidemiological evidence in high-income countries.,Elife. 2020 Mar 24;9. 39. Mercado N, Ito K, Barnes PJ. Accelerated ageing of the lung in COPD: new concepts. Thorax 2015;70:4829. 40. Pascal Andujar, Dominique Courbon, Emilie Bizard, Elisabeth Marcos, Serge Adnot, Laurent Boyer ,Pascal 


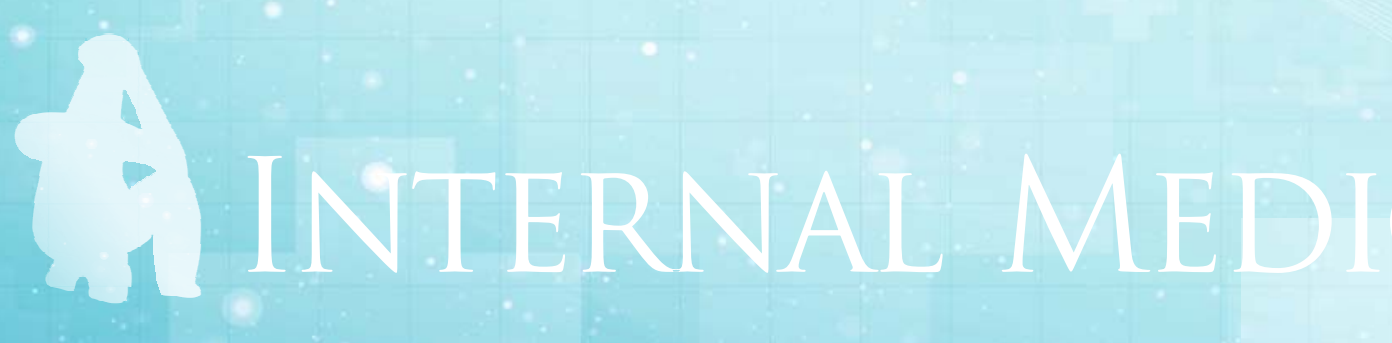

General Reviews

Demoly, Debbie Jarvis, Catherine Neukirch, Isabelle Pin, Gabriel Thabut, Jorge Boczkowski, Bénédicte Leynaert Smoking, telomere length and lung function decline: a longitudinal population based study Thorax Published Online First Accepted 8 May 2017 Thorax 2017;0:13.

41. Salvi, S.S., Brashier, B.B., Londhe, J. et al. Phenotypic comparison between smoking and non-smoking chronic obstructive pulmonary disease. Respir Res 21, 50 (2020).

42. Sposato $B$, Scalese $M$, Milanese $M$, Scichilone $N$, Scala R, Perrella A-Smoking and Obesity Increase Airway Hyperesponsiveness Risk in the Elderly, Curr Aging Sci. 2016;9(4):284-294.)

43. Sadeghimakki, R., \& McCarthy, D. (2019). Interactive effects of adiposity and insulin resistance on the impaired lung function in asthmatic adults: crosssectional analysis of NHANES data. Annals of Human Biology, 121.

44. Lee, J. H., Lee, H. S., \& Lee, Y. J. Lung function as a predictor of incident type 2 diabetes in communitydwelling adults: A longitudinal finding over 12 years from the Korean Genome and Epidemiology Study. Diabetes \& Metabolism, 2019.12.005.

45. Grant, T., Brigham, E. P., \& McCormack, M. C. Childhood Origins of Adult Lung Disease as Opportunities for Prevention. The Journal of Allergy and Clinical Immunology: In Practice,2020, 8(3), 849858

46. Meo SA, Ansary MA, Barayan FR, Almusallam AS, Almehaid AM, Alarifi NS, Alsohaibani TA, Zia I,Electronic Cigarettes: Impact on Lung Function and Fractional Exhaled Nitric Oxide Among Healthy Adults. Am J Mens Health. 2019 Jan-Feb; 13(1)

47. Altered lung biology of healthy never smokers following acute inhalation of E-cigarettes.Staudt MR, SalitJ, Kaner RJ, Hollmann C, Crystal RG,Respir Res. 2018 May 14; 19(1):78

48. Jha $P$, Ramasundarahettige $C$, Landsman $V$, Rostron B, Thun M, Anderson RN, McAfee T, Peto R.-21st-century hazards of smoking and benefits of cessation in the United States. N EnglJ Med. 2013 Jan 24;368(4):341-50

49. Elaine Fuertesa, lana Markevyche, Deborah Jarvisd,
Danielle Vienneauh, Kees de Hooghh, Josep Maria Antóa, Gayan Bowattej, Roberto Bonok, Angelo G. Corsicol, Margareta Emtnern, Thorarinn Gislasono, José Antonio Gullónp, Joachim Heinrichd, John Hendersonq, Mathias Holmr, Ane Johannessens, Bénédicte Leynaertu, Alessandro Marconw, Pierpaolo Marchettiw, Jesús Martínez Moratallax, Silvia Pascualaa, Nicole ProbstHenschh, José Luis Sánchez-Ramosac, Valerie Sirouxad, Johan Sommarae, Joost Weyleraf, Nino Kuenzlih,i, Bénédicte Jacquemina, Judith Garcia-Aymericha, Residential air pollution does not modify the positive association between physical activity and lung function in current smokers in the ECRHS study, Environment International 120 (2018) 364-372

50. Brumpton, B.M., Langhammer, A., Henriksen, A.H., Camargo, C.A., Chen, Y., Romundstad, P.R., et al., 2017. Physical activity and lung function decline in adults with asthma: the HUNT Study. Respirology 22, 278283.

51. Global Initiative for Asthma. Global Strategy for Asthma Management and Prevention, 2015. Available from URL: www.ginasthma.org

52. Hayley Lewthwaite, Tanja W Effing, Timothy Olds and Marie T Williams, Physical activity, sedentary behaviour and sleep in COPD guidelines: A systematic review ,Chronic Respiratory Disease 2017, Vol. 14(3) 231244

53. French Language Pneumology Society. (Recommendation for clinical practice management of COPD). Rev Mal Respir 2010; 27: 522548.

54. Gupta D, Agarwal R, Aggarwal AN, et al. Guidelines for diagnosis and management of chronic obstructive pulmonary disease: joint ICS/NCCP (I) recommendations. Lung India 2013; 30: 228267

55. Ministry of Health Malaysia, Academy of Medicine Malaysia, Malaysian Thoracic Society. Management of chronic obstructive pulmonary disease, http:// www.moh.gov.my/attachments/4749.pdf (2009, accessed 29 April 2016).

56. Miravitlles $M$, Soler-Catalun a JJ, Calle $M$, et al. Spanish guideline for COPD (GesEPOC). Update 2014. Arch Broncopneumol 2014; 50: 116. 2017, Vol. 14(3) 
231244

57. 57. The Institute for Healthcare Improvement $C B O$. (Guideline for the diagnosis and treatment of COPD update March 2010), http://www.nvalt.nl/uploads/Mn/ U9/MnU99pqRBYK7a_zStHhumA/Richtlijn-Diagnos tieken-behandeling-van-COPD-maart-2010.pdf (2010, accessed 27 April 2016).

58. Danish Health Authority. (COPD - Chronic obstructive pulmonary disease: Recommendations for early detection, monitoring, treatment and rehabilitation), http:// www.sst.dk/ /media/F6A8B61402814D59836C0 CE6C710E732.ashx (2007, accessed 29 April 2016).

59. Fuertes $E$, Carsin A-E, Antó JM, et al. Leisure-time vigorous physical activity is associated with better lung function: the prospective ECRHS study. Thorax 2018;73:37684.

60. Garcia-Aymerich J, Lange $P$, Benet $M$, et al. Regular physical activity modifies smoking-related lung function decline and reduces risk of chronic obstructive pulmonary disease. Am J Respir Crit Care Med 2007; 175:45863.

61. Gan, W.Q., Man, S.F.P., Sin, D.D., 2005. The interactions between cigarette smoking and reduced lung function on systemic inflammation. Chest 127 , 558564 .

62. Kasapis, C., Thompson, P.D., 2005. The effects of physical activity on serum C-reactive protein and inflammatory markers: a systematic review. J. Am. Coll. Cardiol. 45,15631569

63. Wang M-L,McCabe L, Petsonk EL, et al. Weight gain and longitudinal changes in lung function in steel workers. Chest 1997;111:152632.

64. Bottai M, Pistelli F, Di Pede F, et al. Longitudinal changes of body mass index, spirometry and diffusion in a general population. Eur Respir J 2002;20:66573.

65. Carey IM, Cook DG, Strachan DP. The effects of adiposity and weight change on forced expiratory volume decline in a longitudinal study of adults. Int J Obes 1999;23:97985.

66. Chen Y, Horne SL, Dosman JA. Body weight and weight gain related to pulmonary function decline in adults: a six year follow up study. Thorax 1993;48:37580. 67. Chinn DJ, Cotes JE, Reed JW. Longitudinal effects of change in body mass on measurements of ventilatory capacity. Thorax 1996;51:699704.

68. Chinn S, Jarvis D, Melotti R, et al. Smoking cessation, lung function, and weight gain:a follow-up study. Lancet 2005;365:162935.

69. Thyagarajan B, Jacobs DR, Apostol GG, et al. Longitudinal association of body mass index with lung function: the CARDIA study. Respir Res 2008;9:31.

70. Pistelli F, Bottai M, Carrozzi L, et al. Changes in obesity status and lung function decline in a general population sample. Respir Med 2008;102:67480.
71. Schikowski T, Schaffner E, Meier F, et al. Improved air quality and attenuated lung function decline: modification by obesity in the SAPALDIA cohort. Environ Health Perspect 2013;121:10349.

72. Baffi CW, Wood L, Winnica $D$, et al. Metabolic syndrome and the lung. Chest 2016;149:152534.

73. Phelan S, Wadden TA, Berkowitz RI, et al. Impact of weight loss on the metabolic syndrome. Int J Obes 2007;31:14428.

74. Chinn S, Jarvis D, Melotti R, et al. Smoking cessation, lung function, and weight gain: a follow-up study. Lancet 2005;365:162935.

75. Fuertes E, Carsin A-E, Antó JM, et al. Leisure-time vigorous physical activity is associated with better lung function: the prospective ECRHS study. Thorax 2018;73:37684.

76. $G$ arcia-Aymerich J, Lange $P$, Benet $M$, et al. Regular physical activity modifies smoking-related lung function decline and reduces risk of chronic obstructive pulmonary disease. Am J Respir Crit Care Med 2007;175:45863.

77. Willemse BWM, Postma DS, Timens $W$, et al. The impact of smoking cessation on respiratory symptoms, lung function, airway hyperresponsiveness and inflammation. Eur RespirJ 2004;23:464 7

78. Ionas Papassotiriou \& Sheikh Mohammed Shariful Islam, Adherence to Mediterranean Diet Is Associated With Lung Function in Older Adults: Data From the Health and Retirement Study, Journal of the American College of Nutrition, ISSN: 0731-5724 (Print) 1541-1087 (Online)

79. Gutierrez-Carrasquilla $L$, Sanchez $E$, Hernandez $M$, Polanco D, Salas-Salvado J, Betriu A, Gaeta AM, Carmona $P$, Purroy $F$, Pamplona $R$, et al. Effects of mediterranean diet and physical activity on pulmonary function: A crosssectional analysis in the ILERVAS project. Nutrients. 2019;11(2):329

80. Rebecca Mc Loughlin, Vanessa Mc Donald, Peter Gibson, Lisa Wood, Weight loss impact on diet quality and eating behaviors for people with obesity and COPD, Nutrients 2017, Oct.

81. L Kathleen Mahan, Janice L Raymond, "Krause's Food and Nutrition care process 2016, 14 ${ }^{\text {th }}$ edition , 689

82. Vanessa M Mc Donald, Lisa G Wood, Anne E Holland, Peter Gibson, "Obesity in COPD: To treat or not to treat? "Expert Review of respiratory medicine $2017 \mathrm{vol} 11$, NO 2, 81-83

83. Ingeborg Farver-Vestergaard, Mia S. O'Toole, Maja O'Connor, Anders Løkke, Elisabeth Bendstrup, Sharee A. Basdeo, Donal J. Cox, Pádraic J. Dunne, Kai Ruggeri, Frances Early, and Robert Zachariae, Mindfulness-based cognitive therapy in COPD: a cluster randomized controlled trial, Eur Respir J 2018; 51: 1702082

84. Durrer Schutz et al, "Management of obesity by GP's" Obesity Facts 2019; 12;40-66 


\section{INTERNAL}

\section{General Reviews}

85. Stoodley I, Williams L,Thompson C, et al. Evidence for lifestyle interventions in asthma. Breathe 2019; 15: e50-e61

86. Global Initiative for Asthma (GINA). Global Strategy for Asthma Management and Prevention. 2018. Available from: https://ginasthma.org

87. Hirota SA, Janssen LJ. Sodium and asthma: something borrowed, something new? Am J Physiol Lung Cell Mol Physiol 2007; 293: L1369L1373.

88. Guo CH, Liu PJ, Lin KP, et al. Nutritional supplement therapy improves oxidative stress, immune response, pulmonaryfunction, and quality of life in allergic asthma patients: an open-label pilot study. Altern Med Rev 2012; 17: 4256 .

89. Wood LG, Garg ML, Powell H, et al. Lycopene-rich treatments modify noneosinophilic airway inflammation in asthma: proof of concept. Free Radic Res 2008; 42: 94102.
90. Wood LG, Garg ML, Smart JM, et al. Manipulating antioxidant intake in asthma: a randomized controlled trial. Am J Clin Nutr 2012; 96: 534543.

91. MCLoughlin RF, Berthon BS, Jensen ME, et al. Shortchain fatty acids, prebiotics, synbiotics, and systemic inflammation: a systematic review and meta-analysis. AmJ Clin Nutr 2017; 106: 930945.

92. West CE, Jenmalm MC, Kozyrskyj AL, et al. Probiotics for treatment and primary prevention of allergic diseases and asthma: looking back and moving forward. Expert Rev Clin Immunol 2016; 12: 625639.

93. van de Pol MA, Lutter R, Smids BS, et al. Synbiotics reduce allergen-induced T-helper 2 response and improve peak expiratory flow in allergic asthmatics. Allergy 2011; 66: 3947.

94. Morton AR, Fitch KD. Australian association for exercise and sports science position statement on exercise and asthma J Sci Med Sport 2011; 14: 312316. 